
\title{
28 Research Suare \\ Exploring the Mechanism of Coagulation Dysfunction in a Sepsis Model though Gene Expression Profiles
}

\section{Ding Li}

Wenzhou Medical University https://orcid.org/0000-0002-9149-4362

\section{Xianwei Zhang}

Wenzhou Medical University

Hongmin Zhou

Wenzhou Medical University

Hao Jiang

Wenzhou Medical University

Yuanyuan Sun

Wenzhou Medical University

\section{Yilun Lu}

Wenzhou Medical University

\section{Fanrong Ye}

Wenzhou Medical University

Shunyao Xu

Wenzhou Medical University

\section{Zhiqiang Chen}

Wenzhou Medical University

Jingye Pan ( $\nabla$ wmupanjingye@126.com )

Wenzhou Medical University

\section{Research Article}

Keywords: Mechanism, Coagulation Dysfunction, Sepsis, Gene Expression Profiles

Posted Date: August 13th, 2021

DOI: https://doi.org/10.21203/rs.3.rs-773558/v1

License: (c) (1) This work is licensed under a Creative Commons Attribution 4.0 International License.

Read Full License 


\section{Abstract}

Objective. Sepsis is a life-threatening condition, and the mechanism of coagulation dysfunction in sepsis remains unknown. We aimed to investigate the mechanism of coagulation dysfunction in sepsis.

Methods. Standard methods were used to establish the sepsis models and generate gene expression profiles. Bioinformatics analysis was carried out by GO and KEGG enrichment analysis, construction of PPIs and screening of seed genes. Finally, seed genes were used to rebuild the disease-related pathways.

Results. Our experiments revealed an inflammatory response and coagulation dysfunction in both animal and cell models. After determining the DEGs, GO and KEGG functional analysis showed that there is a significant correlation between the inflammatory response and DNA damage. PPI network analysis screened 9 seed genes related to cell mitosis and platelet-derived growth factor receptor signaling pathways. Some of the seed genes were relevant to COVID-19.

Conclusions. This study explored the molecular mechanism of coagulation dysfunction in sepsis models by bioinformatics analysis. This may have guiding significance in reducing the risk of complications in patients with sepsis and improving the effectiveness of treatment.

\section{Introduction}

Sepsis is a life-threatening clinical syndrome, that is characterized by an imbalance in the patient's response to infection and organ dysfunction. The definition of sepsis has been refined in the Sepsis-3 guideline, which describes sepsis as continuum from systemic inflammatory response syndrome, sepsis, severe sepsis, to septic shock; and has guided clinical management since its publication in 2016 $(1,2)$.

Inflammation and blood coagulation reinforce on another in the pathogenesis of sepsis(3-5). Macrophages and endothelial cells, as reactive cells, play crucial roles in the inflammatory response and blood coagulation during sepsis(6, 7). Numerous of studies have confirmed that proinflammatory factors such as IL-1 $\beta$, IL-6, TNF-a, etc. play a mediating role in the procoagulant process $(8,9)$. The primary initiator of coagulation tissue factor(Tf) has been reported to play an indispensable role in initiating disseminated intravascular coagulation(DIC) in sepsis induced systemic inflammatory disorders(9, 10) resulting in increasing systemic inflammation and tissue injury.

In response to lipopolysaccharide, LPS, stimulation, macrophages can produce a large number of inflammatory mediators and inducible nitric oxide synthase(iNos) during M1 polarization(11, 12). LPS also drives abnormal inflammation in mammals leading to fatal sepsis(13). However, the mechanism of coagulation dysfunction induced by sepsis remains largely unknown.

Gene expression profiling can detect the expression of thousands of genes simultaneously to reconstruct a global map of cell function which can be used as an important diagnostic tests $(14,15)$. Such 
technology may have a positive impact on improving our understanding of coagulation dysfunction induced by sepsis, facilitating patient screening and the early detection of complications.

Our previous studies found that markers of inflammation and coagulation were elevated in a CLP model or in LPS stimulated macrophages(16). Here, we first used traditional experimental methods to detect changes in inflammation and coagulation function in the CLP model and LPS-stimulated macrophages and then used bioinformatics methods to analyze second-generation sequencing data and obtain seed genes. Finally, qRT-PCR was used to verify the expression of these genes. Our results provide information on coagulation dysfunction in sepsis and may provide potential therapeutic targets for further research.

\section{Materials And Methods}

\subsection{Material}

LPS was purchased from Solarbio (Beijing, China). Phosphate buffered solution(PBS) was purchased from HyClone(GE Healthcare, Utah). Dulbeccos modified Eagle s medium(DMEM) was purchased from Gibco(Life Technologies, Germany). Fetal bovine serum (FBS) was purchased from Gibco(Life Technologies, Germany). The product information of ELISA Kits was shown in Table 1.

\subsection{Cell Treatment to Establish the Sepsis Model}

The murine macrophage cell line RAW264.7 was purchased from the National Collection of Authenticated Cell Cultures (Shanghai, China) and cultured in DMEM supplemented with $10 \% \mathrm{FBS}$ at $37^{\circ} \mathrm{C}$ in a $5 \% \mathrm{CO} 2$ humidified chamber. RAW264.7 cells were stimulated with LPS $(1 \mu \mathrm{g} / \mathrm{ml})$ for 6 hours. Supernatants and cells were obtained for further study.

\subsection{Animals and cecal ligation and puncture (CLP)}

Male C57BL/ 6 mice (8-9 weeks old) were purchased from Charles River Laboratories. All mice were kept in a pathogen-free facility with an ambient temperature of $23 \pm 3^{\circ} \mathrm{C}$, a relative humidity of $55 \pm 10 \%$, and an automatic dark:light cycle of 12:12 hours. Food and water were provided freely. All animal care and experimentation were conducted by us and were approved by the Institutional Animal Care and Use Committees of Wenzhou Medical University.

CLP was used to establish a mouse model of sepsis as described in previous studies(16-

18). Sodium pentobarbital $(1 \%, 0.1 \mathrm{ml} / 10 \mathrm{~g}$ body weight) was used to anesthetize the fasted mice, which were then subjected to midline laparotomy. The cecum was ligated at the lower end of the ileocecal valve and punctured twice with a 21-gauge needle to squeeze out a drop of cecal feces. After replacing the cecum, the abdominal cavity was sealed in two layers, $1 \mathrm{ml}$ of preheated saline was injected subcutaneously for fluid resuscitation, and the animal was returned to the cage. Animals usually recover quickly after surgery and drinking water. Sham mice were also established without ligation or puncture. Plasma and tissue were collected at 24 hours after CLP. 


\subsection{RNA extraction and Microarray Analysis}

This data set includes 6 macrophage samples from the sepsis model, including three biological replicates each of PBS and LPS. RNA was isolated from the samples with TRIzol reagent according to the manufacturer's instructions(19). RNA reverse transcription, library construction, and sequencing were performed at BGI (Shenzhen, China). Microarray analysis was performed on the DNBSEQ platform (BGI, Shenzhen, China).

\subsection{Functional Analysis of Differentially Expressed Genes (DEGs)}

A total of 16,251 genes were detected in all samples and the DEGs were defined in the following steps: (1) Data filtering: Clean reads were obtained from raw reads after a series of quality controls (QCs). SOAPnuke (v1.5.2, BGI, China) was used to filter the reads and for further processing(20). (2) The differentially expressed mRNAs between the control group and LPS-treated group with a certain $p$ value and minimum fold change (FC) were identified using the Limma package(21).

GO and KEGG enrichment analyses of DEGs in LPS-treated RAW264.7 cells were performed using the org.Mm.eg.db package(22). The STRING(23) database (https://string-db.org) is online system for determining interactions between genes or proteins and was used to guide the construction of the proteinprotein interaction (PPI) network to explore functional interactions. Cytoscape is an open-source software platform for visualizing and exploring biomedical networks the offers researchers substantial utility and interactive visualization interface(24). Seed genes and clusters were constructed by MCODE(25) in Cytoscape with following parameters: degree cutoff, 2; cluster finding type, haircut; node score cutoff, 0.2; $\mathrm{K}$-Core, 2; max depth, 100. A heatmap of the seed genes was generated by the heatmap ( $v 1.0 .12)$ package.

The limma package, org.Mm.eg.db package and heatmap package in $\mathrm{R}$ ( $v$ 4.0.2, Bell Laboratories) were used.

\subsection{Reconstruct Pathway for Seed Genes}

Reconstruct Pathway is an online KEGG mapping tool (https://www.kegg.jp/kegg/tool/map_pathway.html) using the Pathway, BRITE (hierarchy and table), and MODULE databases, which can assist in genome and metagenome annotation(26) and rebuild the pathways involving seed genes.

\subsection{Quantitative Real-Time PCR (qRT-PCR)}

Sample preparation for qRT-PCR was performed as described previously $(16,27)$. RNA expression was detected by qRT-PCR which was performed with qPCR Master Mix(TOROGReen, Toroivd) and 7500 Fast machine (Applied Biosystems). The results were analyzed by the $2^{-\Delta \Delta \mathrm{Ct}}$ method(28), and Gapdh was used as an internal standard. Table 2 shows the sequences of the primers. 


\subsection{Western blotting}

The total cell lysate and animal tissue were subjected to SDS-PAGE, and then transferred to a polyvinylidene fluoride (PVDF) membrane (Millipore, Merck KGaA, Darmstadt, Germany). The blot was incubated with primary antibodies and then with horseradish peroxidase (HRP)-conjugated secondary antibodies (Biosharp, Hefei, China), and detected with ECL Plus reagents (Thermo Fisher, USA). The primary antibodies used are listed in Table 3. The relative expression level of Dicer was determined by the density method and normalized to the internal reference expression level using VisionWork LS software(http://www.analytik-jena.com.cn/).

\subsection{ELISA}

The supernatant from in vitro cultured cells or the plasma from experimental mice was quantified using ELISA kits following the manufacturer's protocols.

\subsection{Statistical Analysis}

All experimental data are presented as the means $\pm S D$ of at least three independent experiments. Categorized variables were compared by Student's $t$ test, $P<0.05$ was considered statistically significant.

\section{Results}

\subsection{Establishment of a Model of Inflammation and Coagulation Dysfunction Caused by Sepsis in Mouse}

The mice were treated as described. After 24 hours, we used ELISA to detect the levels of inflammatory factors such as II- $1 \beta, \mathrm{II}-6$ and Tnf- $\alpha$ in the plasma, and found that inflammatory factor levels were higher in CLP group than in the sham group (Fig. 1G). The lung is usually the first organ to become damaged, contributing to pulmonary dysfunction in $\operatorname{septic} \operatorname{shock}(29,30)$. To evaluate CLP-induced lung injury, Hematoxylin and Eosin (HE) staining was used for histological analysis of the lung tissue. CLP significantly destroys the normal structure of lung tissue and causes severe pulmonary interstitial edema (Fig. 1A). Septic acute kidney injury (AKI) is also the most common AKI syndrome in clinical and animal models(31).Fig.1B shows mesenchymal congestion and edema in kidney. We also found that the levels of iNos, Ccl2, II-1 $\beta$, II-6 Tnf- $a$ and Dpp4 were upregulated in the CLP group at both in the mRNA (Fig. 1C and $1 \mathrm{E}$ ) and protein (Fig. 1D and 1F) level. The results described above indicated an inflammatory response in septic mice.

In terms of coagulation dysfunction, we tested the levels of coagulation-related substances in the serum of mice. The levels of Tf, Pai-1, Tat and D-dimer in the CLP group were higher than those in the sham group (Fig. 1H). Simultaneously, qRT-PCR analysis of Tf, Tfpi, t-Pa and Pai-1 found that these substances were elevated in the kidney tissue of the CLP group (Fig 1I), so was the protein level of Tf (Fig. 1H). These results suggested that the mice in the CLP model had coagulation dysfunction.

\subsection{Inflammatory and Coagulatory Responses after LPS Stimulation for 6 hours in Macrophages}


Macrophages are closely associated with inflammatory responses, among which M1 macrophages are mainly involved in proinflammatory responses(32). We detected the level of inflammation in RAW264.7 cells after LPS stimulation for 6 hours, and found that the levels of iNos and Ccl 2 increased in the LPS group (Fig. 2A and 2B). At the same time, the levels of inflammatory mediators such as II-1 $\beta$, II-6 Tnf-a and Dpp4 were also elevated (Fig. 2C and 2D). In the cell supernatant culture medium, we found upregulation of II-1 $\beta, \mathrm{II}-6$ and Tnf-a levels (Fig 2E). The levels of the coagulation-related substances Tf and Pai- 1 increased in the cells and supernatant, respectively (Fig. $2 \mathrm{~F}, 2 \mathrm{G}$ and $2 \mathrm{H}$ ).

\subsection{Differentially expresses gene (DEGs) in macrophages between the PBS group and LPS group}

Quality control of filtered reads was performed with respect to reference genome comparison (Table S1), reference gene analysis (Table S2), random distribution of reads on the transcript (Fig.S1) and sequencing saturation curve (Fig. S2). The data quality control results indicated that our sequencing data were suitable for further analysis. First, the limma package was used to screen 11,921 potential DEGs. Then, different thresholds were used to further screen the different genes. For example, we identified 2715 differentially expressed genes between the PBS group and LPS group, with 716 upregulated and 1999 downregulated by LPS according to the threshold applied. The results using other thresholds are shown in Table 4. This suggested that LPS can cause great changes in macrophage gene levels.

\subsection{GO Enrichment Analysis of DEGs}

To evaluate the function of the DEGs in the sepsis model, we first annotated the genes at level 2(Table 4) to identify $\mathrm{GO}$ analysis. The GO classification analysis showed that there was a strong correlation among genes involved in DNA repair (Fig. 3A). Then, org.Mm.eg.db in $\mathrm{R}$ was used to perform enrichment analysis of the cell component(CC), biological process(BP), and molecular function(MF) categories.

According to GO enrichment analysis, DEGs between the PBS group and LPS group were significantly enriched in DNA replication, DNA repair, cell cycle phase transition, mitotic cell cycle phase transition, DNA-dependent DNA replication, negative regulation of cell cycle, chromosomal region, regulation of mitotic cell cycle phase transition, regulation of cell cycle phase transition and chromosome segregation (Table 5).

\subsection{KEGG Pathway Analysis of DEGs}

The KEGG classification analysis of DEGs is shown in Fig. 3B. The cell cycle pathway was significantly enriched relative to other pathways. The top 10 most highly enriched pathways were as follows: cell cycle, DNA replication, apoptosis, TNF signaling pathway, Epstein-Barr virus infection, hepatitis B, mismatch repair, NF-kappa B signaling pathway, osteoclast differentiation and human T-cell leukemia virus 1 infection (Table 6).

\subsection{PPI Network of the DEGs and Seed Genes.}


To explore whether there are a close and significant relationships among the proteins encoded by the DEGs, a PPI network was constructed from 465 (Level 3, Table 4) candidate DEGs obtained by screening that were significantly enriched. The PPI included 388 nodes and 4498 edges (Fig. 4). PPI enrichment means that there are more interactions between these proteins than would be expected from similarly sized random proteins selected from the mouse genome. Subsequently, to further discover the cluster structure of these proteins, MCODE was used to screen protein clusters and seed genes. Finally, 9 protein clusters with more than 4 genes and the seed genes from each cluster (Bub1b, C5ar1, Ptprj, Zw10, Pfas, Ikbke, Dok2, Ezh2 and Pygb) were defined (Fig. 4, Table S2).

To detect the expression of seed genes, firstly, we counted the expression of seed genes in the sequencing data (Fig. 5A) and calculated the logFC value. C5ar1, Ptprj, lkbke and Dok2 were overexpressed in LPS group, well Bub1b, Zw10, Pfas, Ezh2 and Pygb had low expression (Fig. 5B). Then, the qRT-PCR results verified the expression of seed genes, and the trend was consistent with the sequencing results (Fig. $5 \mathrm{C}$ ).

\subsection{KEGG mapping analysis of the seed genes}

KEGG Mapper was used to reanalyze the seed genes and found that these 9 genes were involved in a total of 29 pathways (Table 7). Pygb, Ezh2 and Pfas were involved in metabolic pathways; C5ar1 and Ikbke were involved in the coronavirus disease-COVID-19 pathway (Fig. 6); and Ikbke was also involved in the Toll-like receptor signaling pathway which was related to inflammation (Fig.7). The gene participating in the most pathways was Ikbke. Other proteins are listed in Table S4.

\section{Discussion}

In sepsis patients, damage to the lungs, kidneys, and cardiovascular system is common and can lead to changes in respiratory function, AKI, DIC, and even death $(4,33)$. The CLP model of sepsis is widely used and very similar to the progress and characteristics of human sepsis. $(18,34)$. In this study, we found that CLP caused lung, kidney and coagulation damage in mice, and LPS stimulation caused changes in markers of inflammation and coagulation in macrophages. These findings indicate the reliability of our model for sequencing and the feasibility of bioinformatics analysis. It has been reported that an increase in Pai-1 levels inhibits urokinase-type plasminogen activator (u-Pa)(4). However, Hoenigl et al. described that sepsis patients with an elevated u-Pa concentration on day 1 after admission had a higher mortality rate than patients with a reduced $\mathrm{u}-\mathrm{Pa}$ concentration(35). Our study verified that the mRNA level of u-Pa was elevated in the mouse kidney in our model, but this was not verified at the protein level. This also shows that the CLP model is highly suitable for the study of immune dysfunction caused by sepsis. However, it is necessary to explore the mechanism of coagulation dysfunction in sepsis for further study.

In this study, a high-throughput genome-wide gene expression analysis was performed, and DEGs were selected from the control and model groups for GO and KEGG analysis. The GO enrichment analysis identified important ontology categories, including DNA replication and DNA repair. By activating tissue damage control, DNA damage response pathways can improve resistance to diseases such as sepsis 
through the complex crosstalk of the DNA damage response and immune response pathways(36). This suggests that the precise replication and repair of DNA is essential for the survival of organisms.

KEGG pathway analysis of DEGs was performed, and 99 pathways were screened out, including cell cycle, DNA replication, apoptosis, and TNF signaling. Caspases are a family of evolutionarily conserved cysteine-dependent proteins that hydrolyze their substrates at specific aspartic acid residues(37). The proper regulation of these proteins is important to prevent the accumulation of apoptotic cells and maintain homeostasis in vivo(38). With inflammatory caspases driving pyroptosis and Inflammatory cytokine secretion, researchers have highlighted the key role of inflammasome activation in host defense against infectious pathogens and inducing fatal shock(38-40). Together, the main analysis results of our GO and KEGG analyses are consistent with those reported in the literature.

We further constructed a PPI network of the 465 top DEGs and identified 9 seed genes: Bub1b, C5ar1, Ptprj, Zw10, Pfas, Ikbke, Dok2, Ezh2, and Pygb. Bub1b, budding uninhibited by benzimidazol 1 homolog beta, is an essential component of the mitotic checkpoint, which Involves the abnormal exit of mitotic arrest that triggers apoptosis of polyploid cells $(41,42)$. C5ar1, complement C5a receptor 1 , is a receptor of chemotactic and inflammatory peptide allergen $\mathrm{C} 5 \mathrm{a}(43,44)$. Ptprj, protein tyrosine phosphatase receptor type $\mathrm{J}$, binds platelet-derived growth factor receptor(45) and negatively regulates the plateletderived growth factor receptor signaling pathway(46). Zw10, a zeste white 10 homolog, plays a role in the spindle assembly machinery depending on its combination in the mitotic RZZ complex(47). Pfas, phosphoribosylformylglycinamidinesynthase, can regulate the activity of phosphoribosylformylglycineamide amidotransferase (FGARAT) and affect the process of IMP synthesis(48). Ikbke (also known as lkke), an inhibitor of nuclear factor kappa B kinase subunit epsilon, is involved in signaling pathways related to TNFA and inflammatory cytokines, such as Interleukin1(49).Dok2, docking protein 2, acts as an enzymatically inert adaptor or scaffolding protein and provides a docking platform for the assembly of multimolecular signaling complexes(50). Ezh2, enhancer of zeste homolog 2, directly controls DNA methylation(51). Pygb, glycogen phosphorylase (brain form), regulates glycogen mobilization(52). All these seed genes are essentially related to inflammation regulation, cell cycle and metabolism, which are consistent with the results of our GO and KEGG analysis above.

Coronavirus Disease 2019 (COVID-19) may lead to organ dysfunction, including acute respiratory distress syndrome (ARDS), shock, and death(53). Although breakthroughs have been made in the development and clinical application of vaccines, their ultimate efficacy has yet to be seen(54-57). We have also achieved a certain effect in clinical treatment(58). However, there is still much room for improvement in the control of COVID-19 pathogenesis and the application of precision medicine. In our study, we found that Increased expression of Ikbke and C5ar1 was associated with the COVID-19 pathway, suggesting that these genes play a certain role in COVID-19 and may be targets for the treatment of COVID-19. Tolllike receptors (TLRs) are protective immune sentinels, that can sense pathogen-related molecular patterns. In innate immune myeloid cells, TLRs induce the secretion of inflammatory cytokines(59). This leads to the recruitment and activation of various kinases including Ikbke. In this study, Ikbke was 
upregulated in the TLR signaling pathway. The activation of Ikbke plays a pivotal role in inflammatory diseases, and we speculate that it can be used as a therapeutic target for more in-depth research.

\section{Conclusions}

There are many complications of coagulation dysfunction caused by sepsis, and the prognosis of this entity. This study aimed to determine the relationship between sepsis and coagulation dysfunction through bioinformatics analysis. The functional analysis of DEGs showed that abnormal expression of Bub1b, C5ar1, Ptprj, Zw10, Pfas, Ikbke, Dok2, Ezh2, and Pygb affected the corresponding functions. It is speculated that these functions play a role in abnormal blood clotting in sepsis, including in COVID-19.

The seed genes we discovered may be instructive in reducing the risk of complications in sepsis patients and improving the effectiveness of treatment. The next step of research will focus on the study of the function of these seed genes and their roles in clinical cases.

\section{Abbreviations}

CLP, cecal ligation and puncture; HE, Hematoxylin and Eosin; iNos, nitric oxide synthase 2; Ccl2, chemokine (C-C motif) ligand 2; Dpp4, dipeptidyl peptidase 4; I-1 $\beta$, interleukin 1 beta; II-6, interleukin 6; Tnf-a, tumor necrosis factor alpha; Tf, tissue factor; Tfpi, tissue factor pathway inhibitor; t-Pa, plasminogen activator, Pai-1, Serpine1.

\section{Declarations}

\section{Conflicts of interest/Competing interests}

The authors declare no conflicts of interest.

\section{Funding}

The study was supported by the National Natural Science Foundation of China $(81873949,81671968)$, Medical Innovation Discipline of Zhejiang Province (Critical Care Medicine, Y2015), Major project cofounded by Zhejiang Province and Ministry of Science and Technology(WKJ-ZJ-1909), Major Science and Technology Project of Wenzhou Science and Technology Bureau(2018ZY002), Applied Research Fund of Wenzhou Science and Technology Bureau(ZG2020012) and The Project of Public Innovation Platform and Carrier in Zhejiang Province(2021E10016).

\section{Conflicts of interest/Competing interests}

The authors declare no conflicts of interest.

\section{Availability of data and material}


The datasets generated during and/or analysed during the current study are not publicly available due to [REASON(S) WHY DATA ARE NOT PUBLIC] but are available from the corresponding author on reasonable request.

Authors' contributions (optional: please review the submission guidelines from the journal whether statements are mandatory)

Ding Li, and Zhiqiang Chen performed the animal experiment; Hongmin Zhou and Hao Jiang performed the cell experiment; Fanrong Ye and Yuanyuan Sun performed R; Jingye Pan and Shunyao Xu designed the experiments; Xianwei Zhang and Yilun Lu wrote and revised the manuscript.

Additional declarations for articles in life science journals that report the results of studies involving humans and/or animals

Procedures involving animals and their care were conducted in conformity with NIH guidelines (NIH Pub. No. 85-23, revised 1996) and was approved by the Institutional Animal Care and Use Committees of Wenzhou Medical University.

\section{Ethics approval (include appropriate approvals or waivers)}

This study was approved by the Scientific Committee of the First Affiliated Hospital of Wenzhou Medical University.

\section{Consent to participate (include appropriate statements)}

All authors declare to participate in the study.

\section{Consent for publication (include appropriate statements)}

All authors declare their consent to the publication of the study results as a paper.

\section{References}

1. Bone R, Balk R, Cerra F, Dellinger R, Fein A, Knaus W, et al. Definitions for sepsis and organ failure and guidelines for the use of innovative therapies in sepsis. The ACCP/SCCM Consensus Conference Committee. American College of Chest Physicians/Society of Critical Care Medicine. Chest (1992) 101(6):1644-55. doi: 10.1378/chest.101.6.1644. PubMed PMID: 1303622.

2. Levy M, Fink M, Marshall J, Abraham E, Angus D, Cook D, et al. 2001 SCCM/ESICM/ACCP/ATS/SIS International Sepsis Definitions Conference. Critical care medicine (2003) 31(4):1250-6. doi: 10.1097/01.ccm.0000050454.01978.3b. PubMed PMID: 12682500.

3. Levi M, van der Poll T. Coagulation and sepsis. Thrombosis research (2017) 149:38-44. doi: 10.1016/j.thromres.2016.11.007. PubMed PMID: 27886531. 
4. Hotchkiss R, Moldawer L, Opal S, Reinhart K, Turnbull I, Vincent J. Sepsis and septic shock. Nature reviews Disease primers (2016) 2:16045. doi: 10.1038/nrdp.2016.45. PubMed PMID: 28117397.

5. Levi $\mathrm{M}$, van der Poll T, Büller $\mathrm{H}$. Bidirectional relation between inflammation and coagulation. Circulation (2004) 109(22):2698-704. doi: 10.1161/01.cir.0000131660.51520.9a. PubMed PMID: 15184294.

6. Qiu P, Liu Y, Zhang J. Review: the Role and Mechanisms of Macrophage Autophagy in Sepsis. Inflammation (2019) 42(1):6-19. doi: 10.1007/s10753-018-0890-8. PubMed PMID: 30194660.

7. Moussa M, Santonocito C, Fagnoul D, Donadello K, Pradier O, Gaussem P, et al. Evaluation of endothelial damage in sepsis-related ARDS using circulating endothelial cells. Intensive care medicine (2015) 41(2):231-8. doi: 10.1007/s00134-014-3589-9. PubMed PMID: 25510299.

8. Wu C, Lu W, Zhang Y, Zhang G, Shi X, Hisada Y, et al. Inflammasome Activation Triggers Blood Clotting and Host Death through Pyroptosis. Immunity (2019) 50(6):1401-11.e4. doi: 10.1016/j.immuni.2019.04.003. PubMed PMID: 31076358.

9. Gando S, Levi M, Toh C. Disseminated intravascular coagulation. Nature reviews Disease primers (2016) 2:16037. doi: 10.1038/nrdp.2016.37. PubMed PMID: 27250996.

10. Maeda T, Wakasawa T, Shima Y, Tsuboi I, Aizawa S, Tamai I. Role of polyamines derived from arginine in differentiation and proliferation of human blood cells. Biological \& pharmaceutical bulletin (2006) 29(2):234-9. doi: 10.1248/bpb.29.234. PubMed PMID: 16462024.

11. Mills $C$, Kincaid K, Alt J, Heilman M, Hill A. M-1/M-2 macrophages and the Th1/Th2 paradigm. Journal of immunology (Baltimore, Md : 1950) (2000) 164(12):6166-73. doi:

10.4049/jimmunol.164.12.6166. PubMed PMID: 10843666.

12. Orecchioni M, Ghosheh Y, Pramod A, Ley K. Macrophage Polarization: Different Gene Signatures in M1(LPS+) vs. Classically and M2(LPS-) vs. Alternatively Activated Macrophages. Frontiers in immunology (2019) 10:1084. doi: 10.3389/fimmu.2019.01084. PubMed PMID: 31178859.

13. Rosadini C, Kagan J. Early innate immune responses to bacterial LPS. Current opinion in immunology (2017) 44:14-9. doi: 10.1016/j.coi.2016.10.005. PubMed PMID: 27842237.

14. Cheung A. Molecular targets in gynaecological cancers. Pathology (2007) 39(1):26-45. doi: 10.1080/00313020601153273. PubMed PMID: 17365821.

15. Magic Z, Radulovic S, Brankovic-Magic M. cDNA microarrays: identification of gene signatures and their application in clinical practice. Journal of BUON : official journal of the Balkan Union of Oncology (2007):S39-44. PubMed PMID: 17935276.

16. Xu S, Pan X, Mao L, Pan H, Xu W, Hu Y, et al. Phospho-Tyr705 of STAT3 is a therapeutic target for sepsis through regulating inflammation and coagulation. Cell communication and signaling: CCS (2020) 18(1):104. doi: 10.1186/s12964-020-00603-z. PubMed PMID: 32641132.

17. Hubbard W, Choudhry M, Schwacha M, Kerby J, Rue L, Bland K, et al. Cecal ligation and puncture. Shock (Augusta, Ga) (2005):52-7. doi: 10.1097/01.shk.0000191414.94461.7e. PubMed PMID: 16374373. 
18. Dejager L, Pinheiro I, Dejonckheere E, Libert C. Cecal ligation and puncture: the gold standard model for polymicrobial sepsis? Trends in microbiology (2011) 19(4):198-208. doi:

10.1016/j.tim.2011.01.001. PubMed PMID: 21296575.

19. Vikhe Patil K, Canlon B, Cederroth CR. High quality RNA extraction of the mammalian cochlea for qRT-PCR and transcriptome analyses. Hear Res (2015) 325:42-8. Epub 2015/03/31. doi: 10.1016/j.heares.2015.03.008. PubMed PMID: 25818515.

20. Cock PJ, Fields CJ, Goto N, Heuer ML, Rice PM. The Sanger FASTQ file format for sequences with quality scores, and the Solexa/Illumina FASTQ variants. Nucleic Acids Res (2010) 38(6):1767-71. Epub 2009/12/18. doi: 10.1093/nar/gkp1137. PubMed PMID: 20015970; PubMed Central PMCID: PMCPMC2847217.

21. Ritchie ME, Phipson B, Wu D, Hu Y, Law CW, Shi W, et al. limma powers differential expression analyses for RNA-sequencing and microarray studies. Nucleic Acids Res (2015) 43(7):e47. Epub 2015/01/22. doi: 10.1093/nar/gkv007. PubMed PMID: 25605792; PubMed Central PMCID: PMCPMC4402510.

22. Huber W, Carey VJ, Gentleman R, Anders S, Carlson M, Carvalho BS, et al. Orchestrating highthroughput genomic analysis with Bioconductor. Nat Methods (2015) 12(2):115-21. Epub 2015/01/31. doi: 10.1038/nmeth.3252. PubMed PMID: 25633503; PubMed Central PMCID: PMCPMC4509590.

23. Szklarczyk D, Gable AL, Lyon D, Junge A, Wyder S, Huerta-Cepas J, et al. STRING v11: protein-protein association networks with increased coverage, supporting functional discovery in genome-wide experimental datasets. Nucleic Acids Res (2019) 47(D1):D607-D13. Epub 2018/11/27. doi: 10.1093/nar/gky1131. PubMed PMID: 30476243; PubMed Central PMCID: PMCPMC6323986.

24. Shannon P, Markiel A, Ozier O, Baliga NS, Wang JT, Ramage D, et al. Cytoscape: a software environment for integrated models of biomolecular interaction networks. Genome Res (2003) 13(11):2498-504. Epub 2003/11/05. doi: 10.1101/gr.1239303. PubMed PMID: 14597658; PubMed Central PMCID: PMCPMC403769.

25. Bader $\mathrm{G}$, Hogue $\mathrm{C}$. An automated method for finding molecular complexes in large protein interaction networks. BMC bioinformatics (2003) 4(2):1-27. doi: 10.1186/1471-2105-4-2. PubMed PMID: 12525261.

26. Kanehisa M, Furumichi M, Sato Y, Ishiguro-Watanabe M, Tanabe M. KEGG: integrating viruses and cellular organisms. Nucleic acids research (2020). doi: 10.1093/nar/gkaa970. PubMed PMID: 33125081.

27. Li D, Ni X, Tang H, Zhang J, Zheng C, Lin J, et al. KRT17 Functions as a Tumor Promoter and Regulates Proliferation, Migration and Invasion in Pancreatic Cancer via mTOR/S6k1 Pathway. Cancer management and research (2020) 12:2087-95. doi: 10.2147/cmar.s243129. PubMed PMID: 32256116.

28. Livak K, Schmittgen T. Analysis of relative gene expression data using real-time quantitative PCR and the 2(-Delta Delta C(T)) Method. Methods (San Diego, Calif) (2001) 25(4):402-8. doi: 
10.1006/meth.2001.1262. PubMed PMID: 11846609.

29. Bersten A, Sibbald W. Acute lung injury in septic shock. Critical care clinics (1989) 5(1):49-79. doi: 10.1016/s0749-0704(18)30450-0. PubMed PMID: 2647226.

30. Welbourn C, Young Y. Endotoxin, septic shock and acute lung injury: neutrophils, macrophages and inflammatory mediators. The British journal of surgery (1992) 79(10):998-1003. doi:

10.1002/bjs.1800791006. PubMed PMID: 1422741.

31. Bellomo R, Kellum J, Ronco C, Wald R, Martensson J, Maiden M, et al. Acute kidney injury in sepsis. Intensive care medicine (2017) 43(6):816-28. doi: 10.1007/s00134-017-4755-7. PubMed PMID: 28364303.

32. Yunna C, Mengru H, Lei W, Weidong C. Macrophage M1/M2 polarization. European journal of pharmacology (2020) 877:173090. doi: 10.1016/j.ejphar.2020.173090. PubMed PMID: 32234529.

33. White L, Hassoun H, Bihorac A, Moore L, Sailors R, McKinley B, et al. Acute kidney injury is surprisingly common and a powerful predictor of mortality in surgical sepsis. The journal of trauma and acute care surgery (2013) 75(3):432-8. doi: 10.1097/TA.0b013e31829de6cd. PubMed PMID: 24089113.

34. Wichterman K, Baue A, Chaudry I. Sepsis and septic shock-a review of laboratory models and a proposal. The Journal of surgical research (1980) 29(2):189-201. doi: 10.1016/0022-4804(80)900372. PubMed PMID: 6997619.

35. Hoenigl M, Raggam R, Wagner J, Prueller F, Grisold A, Leitner E, et al. Procalcitonin fails to predict bacteremia in SIRS patients: a cohort study. International journal of clinical practice (2014) 68(10):1278-81. doi: 10.1111/ijcp.12474. PubMed PMID: 24898888.

36. Neves-Costa A, Moita L. Modulation of inflammation and disease tolerance by DNA damage response pathways. The FEBS journal (2017) 284(5):680-98. doi: 10.1111/febs.13910. PubMed PMID: 27686576.

37. Lamkanfi M, Declercq W, Kalai M, Saelens X, Vandenabeele P. Alice in caspase land. A phylogenetic analysis of caspases from worm to man. Cell death and differentiation (2002) 9(4):358-61. doi: 10.1038/sj.cdd.4400989. PubMed PMID: 11965488.

38. Van Opdenbosch N, Lamkanfi M. Caspases in Cell Death, Inflammation, and Disease. Immunity (2019) 50(6):1352-64. doi: 10.1016/j.immuni.2019.05.020. PubMed PMID: 31216460.

39. Van Gorp H, Van Opdenbosch N, Lamkanfi M. Inflammasome-Dependent Cytokines at the Crossroads of Health and Autoinflammatory Disease. Cold Spring Harbor perspectives in biology (2019) 11(1):shed online January 2, 2019.https://doi.org/10.1101/cshperspect.a028563. doi: 10.1101/cshperspect.a028563. PubMed PMID: 29038114.

40. Vanden Berghe T, Demon D, Bogaert P, Vandendriessche B, Goethals A, Depuydt B, et al. Simultaneous targeting of IL-1 and IL-18 is required for protection against inflammatory and septic shock. American journal of respiratory and critical care medicine (2014) 189(3):282-91. doi: 10.1164/rccm.201308-15350C. PubMed PMID: 24456467. 
41. Chan G, Jablonski S, Sudakin V, Hittle J, Yen T. Human BUBR1 is a mitotic checkpoint kinase that monitors CENP-E functions at kinetochores and binds the cyclosome/APC. The Journal of cell biology (1999) 146(5):941-54. doi: 10.1083/jcb.146.5.941. PubMed PMID: 10477750.

42. Johnson V, Scott M, Holt S, Hussein D, Taylor S. Bub1 is required for kinetochore localization of BubR1, Cenp-E, Cenp-F and Mad2, and chromosome congression. Journal of cell science (2004) 117:1577-89. doi: 10.1242/jcs.01006. PubMed PMID: 15020684.

43. Gerard N, Gerard C. The chemotactic receptor for human C5a anaphylatoxin. Nature (1991) 349(6310):614-7. doi: 10.1038/349614a0. PubMed PMID: 1847994.

44. DeMartino J, Van Riper G, Siciliano S, Molineaux C, Konteatis Z, Rosen H, et al. The amino terminus of the human $\mathrm{C} 5 \mathrm{a}$ receptor is required for high affinity $\mathrm{C} 5 \mathrm{a}$ binding and for receptor activation by $\mathrm{C} 5 \mathrm{a}$ but not C5a analogs. The Journal of biological chemistry (1994) 269(20):14446-50. PubMed PMID: 8182049.

45. Kovalenko M, Denner K, Sandström J, Persson C, Gross S, Jandt E, et al. Site-selective dephosphorylation of the platelet-derived growth factor beta-receptor by the receptor-like proteintyrosine phosphatase DEP-1. The Journal of biological chemistry (2000) 275(21):16219-26. doi: 10.1074/jbc.275.21.16219. PubMed PMID: 10821867.

46. Kellie S, Craggs G, Bird I, Jones G. The tyrosine phosphatase DEP-1 induces cytoskeletal rearrangements, aberrant cell-substratum interactions and a reduction in cell proliferation. Journal of cell science (2004) 117:609-18. doi: 10.1242/jcs.00879. PubMed PMID: 14709717.

47. Kops G, Kim Y, Weaver B, Mao Y, McLeod I, Yates J, et al. ZW10 links mitotic checkpoint signaling to the structural kinetochore. The Journal of cell biology (2005) 169(1):49-60. doi:

10.1083/jcb.200411118. PubMed PMID: 15824131.

48. Patterson D, Bleskan J, Gardiner K, Bowersox J. Human phosphoribosylformylglycineamide amidotransferase (FGARAT): regional mapping, complete coding sequence, isolation of a functional genomic clone, and DNA sequence analysis. Gene(1999) 239(2):381-91. doi: 10.1016/s03781119(99)00378-9. PubMed PMID: 10548741.

49. Clark K, Peggie M, Plater L, Sorcek R, Young E, Madwed J, et al. Novel cross-talk within the IKK family controls innate immunity. The Biochemical journal (2011) 434(1):93-104. doi: 10.1042/bj20101701. PubMed PMID: 21138416.

50. Némorin J, Duplay P. Evidence that Llck-mediated phosphorylation of p56dok and p62dok may play a role in CD2 signaling. The Journal of biological chemistry (2000) 275(19):14590-7. doi: 10.1074/jbc.275.19.14590. PubMed PMID: 10799545.

51. Viré E, Brenner C, Deplus R, Blanchon L, Fraga M, Didelot C, et al. The Polycomb group protein EZH2 directly controls DNA methylation. Nature (2006) 439(7078):871-4. doi: 10.1038/nature04431. PubMed PMID: 16357870.

52. Mathieu C, Li de la Sierra-Gallay I, Duval R, Xu X, Cocaign A, Léger T, et al. Insights into Brain Glycogen Metabolism: THE STRUCTURE OF HUMAN BRAIN GLYCOGEN PHOSPHORYLASE. The 
Journal of biological chemistry (2016) 291(35):18072-83. doi: 10.1074/jbc.M116.738898. PubMed PMID: 27402852.

53. Zhou F, Yu T, Du R, Fan G, Liu Y, Liu Z, et al. Clinical course and risk factors for mortality of adult inpatients with COVID-19 in Wuhan, China: a retrospective cohort study. Lancet (London, England) (2020) 395(10229):1054-62. doi: 10.1016/s0140-6736(20)30566-3. PubMed PMID: 32171076.

54. Jeyanathan M, Afkhami S, Smaill F, Miller M, Lichty B, Xing Z. Immunological considerations for COVID-19 vaccine strategies. Nature reviews Immunology (2020) 20(10):615-32. doi: 10.1038/s41577-020-00434-6. PubMed PMID: 32887954.

55. Haynes B, Corey L, Fernandes P, Gilbert P, Hotez P, Rao S, et al. Prospects for a safe COVID-19 vaccine. Science translational medicine (2020) 12(568):1-16. doi: 10.1126/scitranslmed.abe0948. PubMed PMID: 33077678.

56. Shin M, Shukla S, Chung Y, Beiss V, Chan S, Ortega-Rivera O, et al. COVID-19 vaccine development and a potential nanomaterial path forward. Nature nanotechnology (2020) 15(8):646-55. doi: 10.1038/s41565-020-0737-y. PubMed PMID: 32669664.

57. van Riel D, de Wit E. Next-generation vaccine platforms for COVID-19. Nature materials (2020) 19(8):810-2. doi: 10.1038/s41563-020-0746-0. PubMed PMID: 32704139.

58. Chen C, Qi F, Shi K, Li Y, Li J, Chen Y, et al. Thalidomide combined with low-dose short-term glucocorticoid in the treatment of critical Coronavirus Disease 2019. Clinical and translational medicine (2020) 10(2):e35. doi: 10.1002/ctm2.35. PubMed PMID: 32508009.

59. Barton G, Kagan J. A cell biological view of Toll-like receptor function: regulation through compartmentalization. Nature reviews Immunology (2009) 9(8):535-42. doi: 10.1038/nri2587. PubMed PMID: 19556980.

\section{Tables}

Table 1. Information for ELISA Kits

\begin{tabular}{|lll|}
\hline Terms & Manufacturer & Location \\
\hline IL-1 $\beta$ IIL-6 and TNF-a & $\begin{array}{l}\text { MULTISCIENCES\&LIANKE) } \\
\text { BIOTECH,CO.,LTD }\end{array}$ & $\begin{array}{l}\text { Hangzhou, } \\
\text { China }\end{array}$ \\
$\begin{array}{l}\text { D-Dimer(D2D), Thrombin-antithrombin } \\
\text { complex (TAT) }\end{array}$ & WUHAN HUAMEI BIOTECH CO.,LTD & Wuhan, China \\
\hline Serpin E1/PAl-1, Coagulation Factor/TF, & R\&D SYSTEMS, Bio-techne & MN, USA \\
\hline
\end{tabular}

Table 2. Sequences of the primers used for qRT- PCR 


\begin{tabular}{|c|c|c|}
\hline Gene & Forward primer $\left(5^{\prime}-3^{\prime}\right)$ & Reverse primer $\left(5^{\prime}-3^{\prime}\right)$ \\
\hline Gapdh & AGGTCGGTGTGAACGGATTTG & GGGGTCGTTGATGGCAACA \\
\hline$\|-1 \beta$ & GCTGCTTCCAAАCCTTTGAC & СТTСТССАСAGCCACAATGA \\
\hline$\| 1-6$ & AGTTGCCTTCTTGGGACTGA & CCTCCGACTTGTGAAGTGGT \\
\hline Tnf-a & GTGGGTGAGGAGCACGTAGT & CGATCACCCCGAAGTTCAGTAG \\
\hline Dpp4 & ССССТСТАСАСТСТАСАТСG & TTTGAAGGCATCTGGACAT \\
\hline iNos & TGCCACGGACGAGACGGATAG & СТCTTCAAGCACCTCCAGGAACG \\
\hline Ccl2 & GCACCAGCACCAGCCAACTC & GAATGAGTAGCAGCAGGTGAGTGG \\
\hline Tf & GCCACCATCTTTATCATCCTCC & AGCCTTTCCTCTATGCCAAGC \\
\hline Pai-1 & GCACAGGCACTGCAAAAGG & GGGCTGAGATGACAAAGGCT \\
\hline Tfpi & GGGCCACTGTGTGTCTGTT & GCACAAAATGTATGTAGCGGTTT \\
\hline $\mathrm{t}-\mathrm{Pa}$ & AGATGAGCCAACGCAGACAA & AACTTCGGACAGGCACTGAG \\
\hline
\end{tabular}

Table 3. Information for primary antibodies 


\begin{tabular}{|c|c|c|c|c|}
\hline Terms & Abbreviation & $\begin{array}{c}\text { Catalog } \\
\text { number }\end{array}$ & Manufacturer & Location \\
\hline $\begin{array}{l}\text { Beta Tubulin Polyclonal } \\
\text { Antibody }\end{array}$ & $\beta$-tubulin & 10094-1-AP & Proteintech & $\begin{array}{l}\text { Wuhan, } \\
\text { P.R.C }\end{array}$ \\
\hline INOS Polyclonal Antibody & iNos & 18985-1-AP & Proteintech & $\begin{array}{l}\text { Wuhan, } \\
\text { P.R.C }\end{array}$ \\
\hline $\begin{array}{l}\text { Mcp1(Ccl2) Monoclonal } \\
\text { Antibody }\end{array}$ & $\mathrm{Ccl} 2$ & 66272-1-lg & Proteintech & $\begin{array}{l}\text { Wuhan, } \\
\text { P.R.C }\end{array}$ \\
\hline Anti-IL-1 beta antibody & $I I-1 \beta$ & ab234437 & Abcam & $\begin{array}{l}\text { Cambridge, } \\
\text { UK }\end{array}$ \\
\hline IL-6 Monoclonal Antibody & II-6 & 66146-1-lg & Proteintech & $\begin{array}{l}\text { Wuhan, } \\
\text { P.R.C }\end{array}$ \\
\hline TNF-a (D2D4) Rabbit mAb & Tnf-a & $11948 \mathrm{~T}$ & $\begin{array}{l}\text { Cell Signaling } \\
\text { Technology }\end{array}$ & $\begin{array}{l}\text { Danvers, } \\
\text { MA }\end{array}$ \\
\hline $\begin{array}{l}\text { DPP4/CD26 (D6D8K) Rabbit } \\
\text { mAb }\end{array}$ & Dpp4 & $67138 S$ & $\begin{array}{l}\text { Cell Signaling } \\
\text { Technology }\end{array}$ & $\begin{array}{l}\text { Danvers, } \\
\text { MA }\end{array}$ \\
\hline Anti-Tissue Factor antibody & Tf & ab151748 & Abcam & $\begin{array}{l}\text { Cambridge, } \\
\text { UK }\end{array}$ \\
\hline GAPDH Polyclonal Antibody & Gapdh & 10494-1-AP & Proteintech & $\begin{array}{l}\text { Wuhan, } \\
\text { P.R.C }\end{array}$ \\
\hline
\end{tabular}

Table 4. Intercept DEGs with different thresholds

\begin{tabular}{|llllll|}
\hline Serial & logFC & adj.P.Val & Upregulation & Downregulation & Total \\
\hline $\mathbf{1}$ & $>2$ & $<0.01$ & 1118 & 3412 & 4530 \\
\hline $\mathbf{2}$ & $>2$ & $<0.001$ & 716 & 1999 & 2715 \\
\hline $\mathbf{3}$ & $>10$ & $<0.0001$ & 188 & 277 & 465 \\
\hline
\end{tabular}

Table 5. Top 10 enriched $\mathrm{GO}$ terms sorted in ascending order by p.adjust 


\begin{tabular}{|lllll|}
\hline ONTOLOGY & ID & Description & p.adjust & Count \\
\hline BP & GO:0006260 & DNA replication & $9.88 \mathrm{E}-27$ & 95 \\
\hline BP & GO:0006281 & DNA repair & $2.66 \mathrm{E}-26$ & 142 \\
\hline BP & GO:0044770 & cell cycle phase transition & $2.31 \mathrm{E}-23$ & 124 \\
\hline BP & GO:0044772 & mitotic cell cycle phase transition & $1.35 \mathrm{E}-22$ & 115 \\
\hline BP & GO:0006261 & DNA-dependent DNA replication & $1.08 \mathrm{E}-21$ & 61 \\
\hline BP & GO:0045786 & negative regulation of cell cycle & $3.84 \mathrm{E}-21$ & 126 \\
\hline CC & GO:0098687 & chromosomal region & $1.12 \mathrm{E}-20$ & 97 \\
\hline BP & GO:1901990 & regulation of mitotic cell cycle phase transition & $6.23 \mathrm{E}-18$ & 85 \\
\hline BP & GO:1901987 & regulation of cell cycle phase transition & $7.70 \mathrm{E}-18$ & 91 \\
\hline BP & GO:0007059 & chromosome segregation & $2.93 \mathrm{E}-17$ & 95 \\
\hline
\end{tabular}

Table 6. Top 10 enriched KEGG terms sorted in ascending order by p.adjust

\begin{tabular}{|llll|}
\hline ID & Description & p.adjust & Count \\
\hline mmu04110 & Cell cycle & $1.80 \mathrm{E}-14$ & 55 \\
\hline mmu03030 & DNA replication & $3.68 \mathrm{E}-10$ & 23 \\
\hline mmu04210 & Apoptosis & $6.70 \mathrm{E}-08$ & 47 \\
\hline mmu04668 & TNF signaling pathway & $1.19 \mathrm{E}-07$ & 41 \\
\hline mmu05169 & Epstein-Barr virus infection & $1.94 \mathrm{E}-07$ & 66 \\
\hline mmu05161 & Hepatitis B & $2.96 \mathrm{E}-07$ & 51 \\
\hline mmu03430 & Mismatch repair & $2.96 \mathrm{E}-07$ & 15 \\
\hline mmu04064 & NF-kappa B signaling pathway & $2.96 \mathrm{E}-07$ & 39 \\
\hline mmu04380 & Osteoclast differentiation & $2.96 \mathrm{E}-07$ & 43 \\
\hline mmu05166 & Human T-cell leukemia virus 1 infection & $2.96 \mathrm{E}-07$ & 68 \\
\hline
\end{tabular}

Table 7. KEGG pathway analysis of the seed genes 


\begin{tabular}{|c|c|c|}
\hline Terms & Description & Genes \\
\hline mmu01100 & Metabolic pathways & Pygb, Ezh2,Pfas \\
\hline mmu05171 & Coronavirus disease - COVID-19 & C5ar1,lkbke \\
\hline mmu05169 & Epstein-Barr virus infection & lkbke \\
\hline mmu04623 & Cytosolic DNA-sensing pathway & lkbke \\
\hline mmu05162 & Measles & lkbke \\
\hline mmu05166 & Human T-cell leukemia virus 1 infection & Bub1b \\
\hline mmu04621 & NOD-like receptor signaling pathway & lkbke \\
\hline mmu05168 & Herpes simplex virus 1 infection & Ikbke \\
\hline mmu04922 & Glucagon signaling pathway & Pygb \\
\hline mmu05150 & Staphylococcus aureus infection & C5ar1 \\
\hline mmu04622 & RIG-I-like receptor signaling pathway & Ikbke \\
\hline mmu05161 & Hepatitis B & lkbke \\
\hline mmu04620 & Toll-like receptor signaling pathway & lkbke \\
\hline mmu04910 & Insulin signaling pathway & Pygb \\
\hline mmu05206 & MicroRNAs in cancer & Ezh2 \\
\hline mmu04610 & Complement and coagulation cascades & C5ar1 \\
\hline mmu00500 & Starch and sucrose metabolism & Pygb \\
\hline mmu04110 & Cell cycle & Bub1b \\
\hline mmu04217 & Necroptosis & Pygb \\
\hline mmu05164 & Influenza A & Ikbke \\
\hline mmu05160 & Hepatitis C & Ikbke \\
\hline mmu05167 & Kaposi sarcoma-associated herpesvirus infection & lkbke \\
\hline mmu00310 & Lysine degradation & Ezh2 \\
\hline mmu04080 & Neuroactive ligand-receptor interaction & C5ar1 \\
\hline mmu04657 & IL-17 signaling pathway & lkbke \\
\hline mmu04625 & C-type lectin receptor signaling pathway & lkbke \\
\hline mmu05165 & Human papillomavirus infection & lkbke \\
\hline mmu04931 & Insulin resistance & Pygb \\
\hline
\end{tabular}




\section{Figures}

a
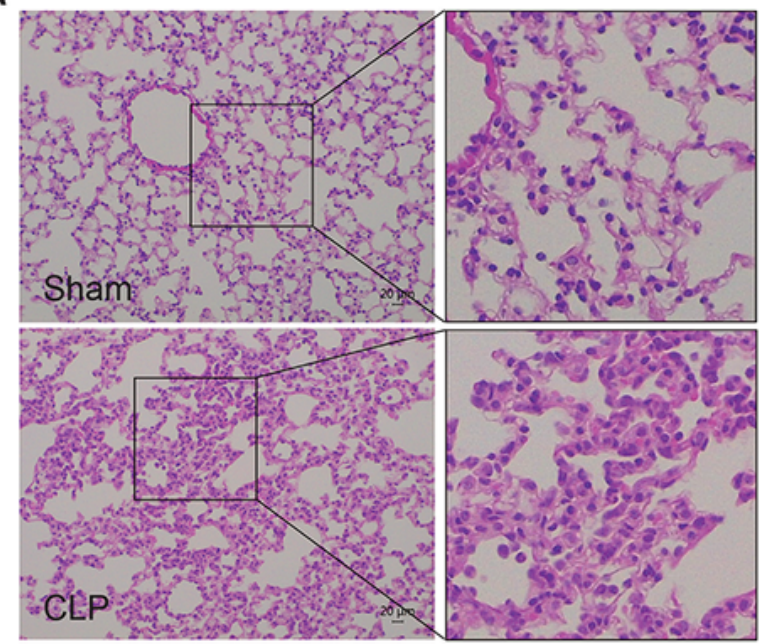

C

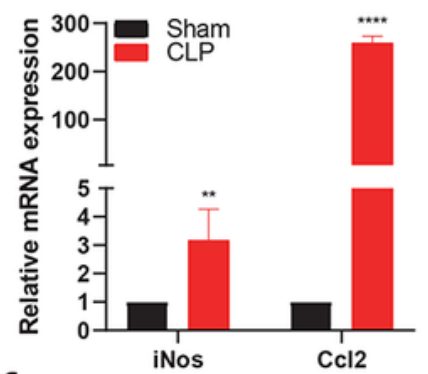

$f$
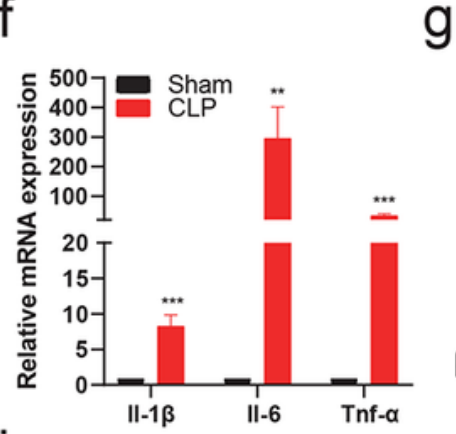

i d b

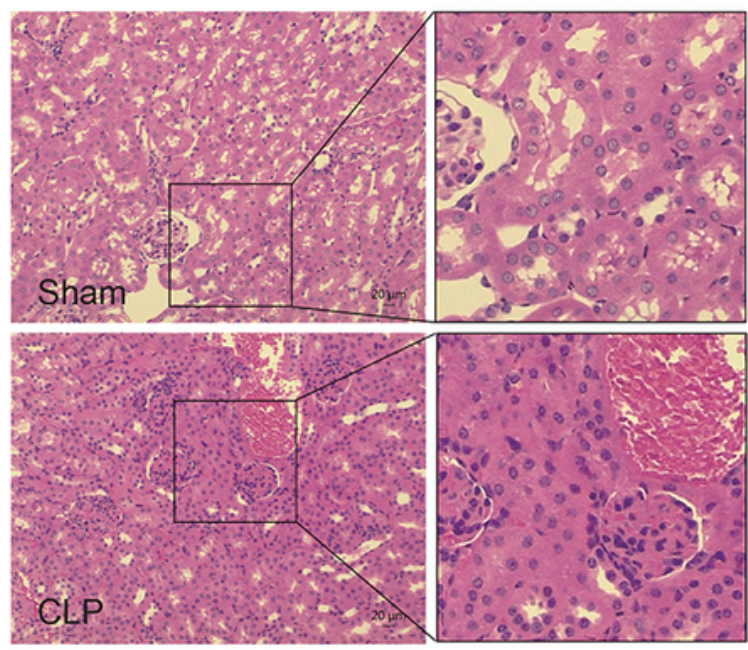

e

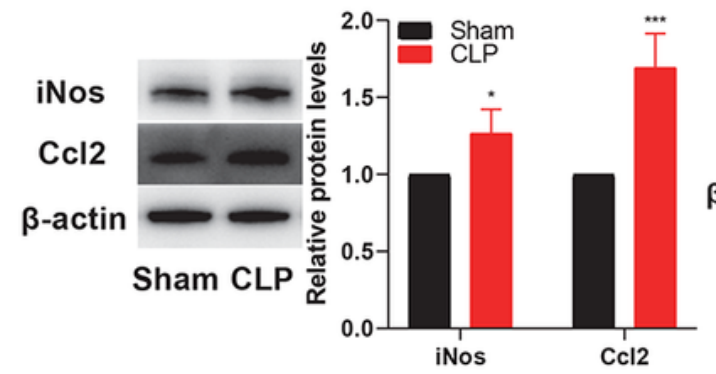

g
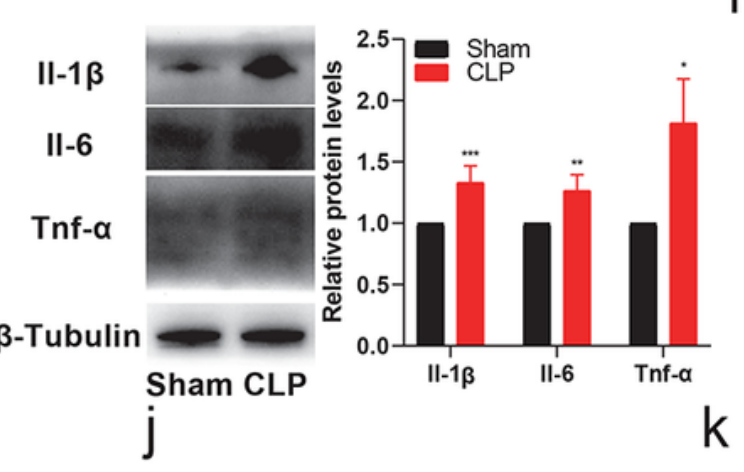

$\mathrm{h}$
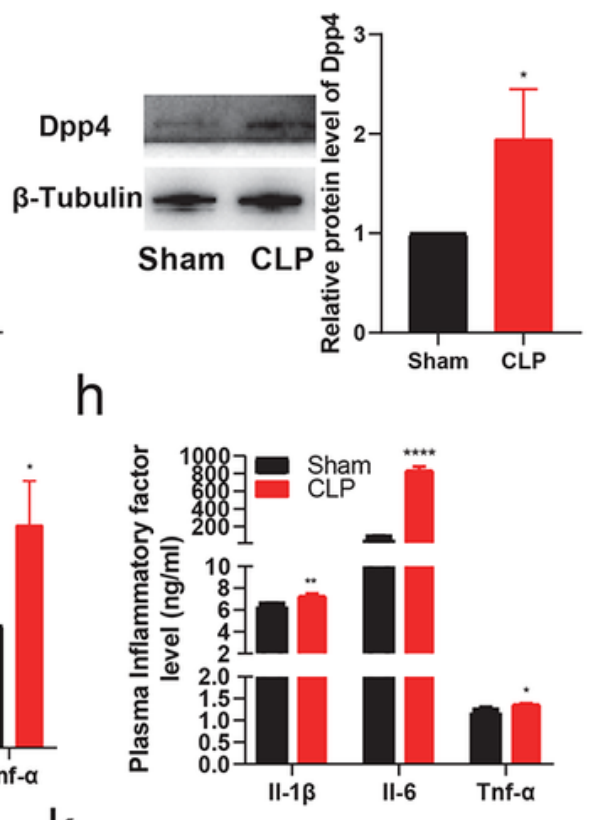
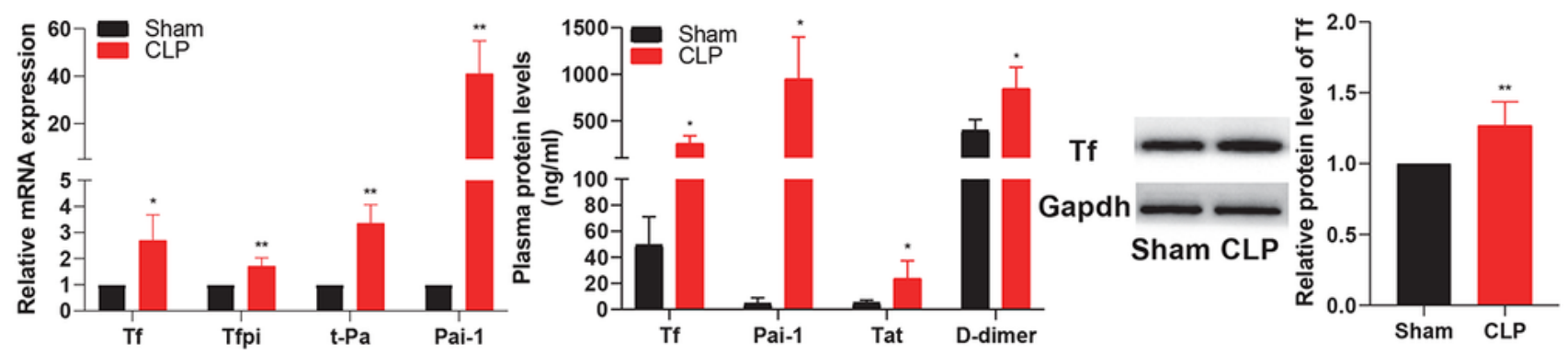

Figure 1 
Systemitic injury in CLP-induced polymicrobial sepsis in mouse. Lung(A) and kidney(B) tissue sections were stained with HE $24 \mathrm{~h}$ after CLP for histological examination. qRT-PCR(C) and WB(D) analysis of

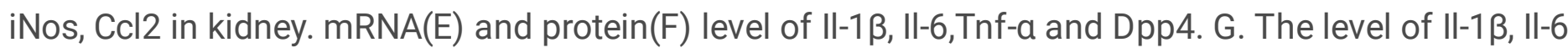
and Tnf-a in plasma. H. ELISA analysis of Tf, Pai-1, Tat and D-dimer. I. Relative mRNA analysis of coagulation material (Tf, Tfpi, t-Pa and Pai-1) in kidney. J. Protein level of Tf in kidney.(n=3-6 per group, results are the mean $\pm S E M$; $t$-student test. ${ }^{*}$ v.s. Con group; ${ }^{*} P<0.05,{ }^{*} P<<0.01,{ }^{*} * * P<0.001,{ }^{*} * \star * P<0.0001$.)
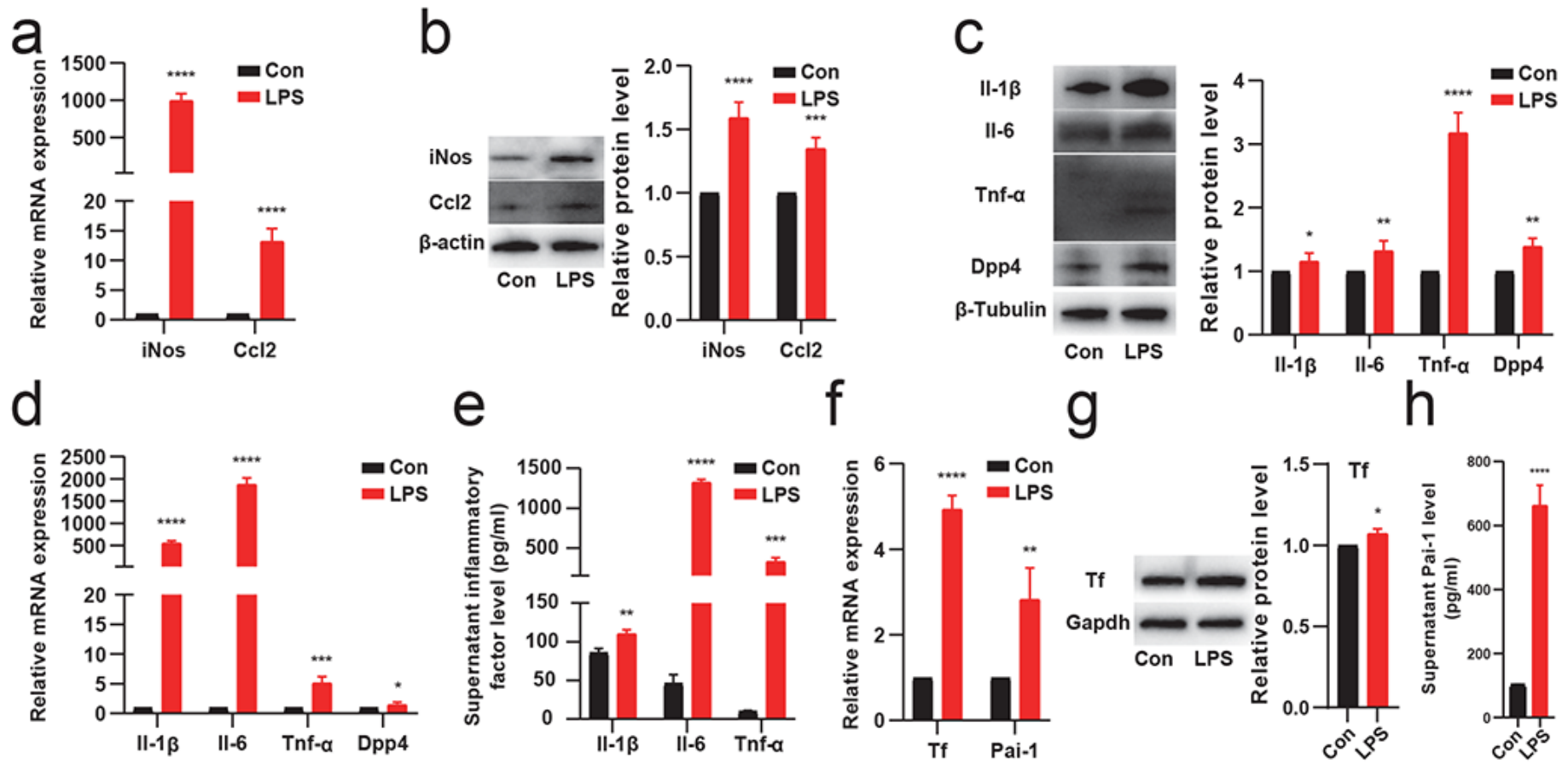

\section{Figure 2}

Inflammatory and coagulatory responses after LPS stimulation for 6 hours in RAW264.7. qRT-PCR(A) and

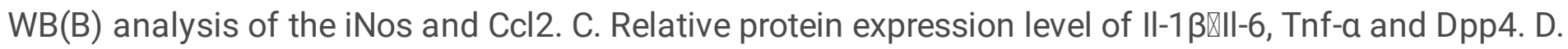
Relative mRNA level of II-1 $\beta$, II-6, Tnf- $\alpha$ and Dpp4. E. ELISA for II-1 $\beta$, II-6 Tnf- $\alpha$ and Pai-1 in macrophage supernatant. F. Relative mRNA expression of Tf and Pai-1. G. Relative protein level of Tf in s in macrophages were assayed by immunoblotting. $\mathrm{H}$. The level of PAl- 1 in the cell supernatant. $(n=3-6$ per group, results are the mean $\pm S D$; t-student test. * v.s. Con group; ${ }^{*}<<0.05,{ }^{*} P<0.01,{ }^{*} * P<0.001$, $\star \star \star \star P<0.0001)$. 


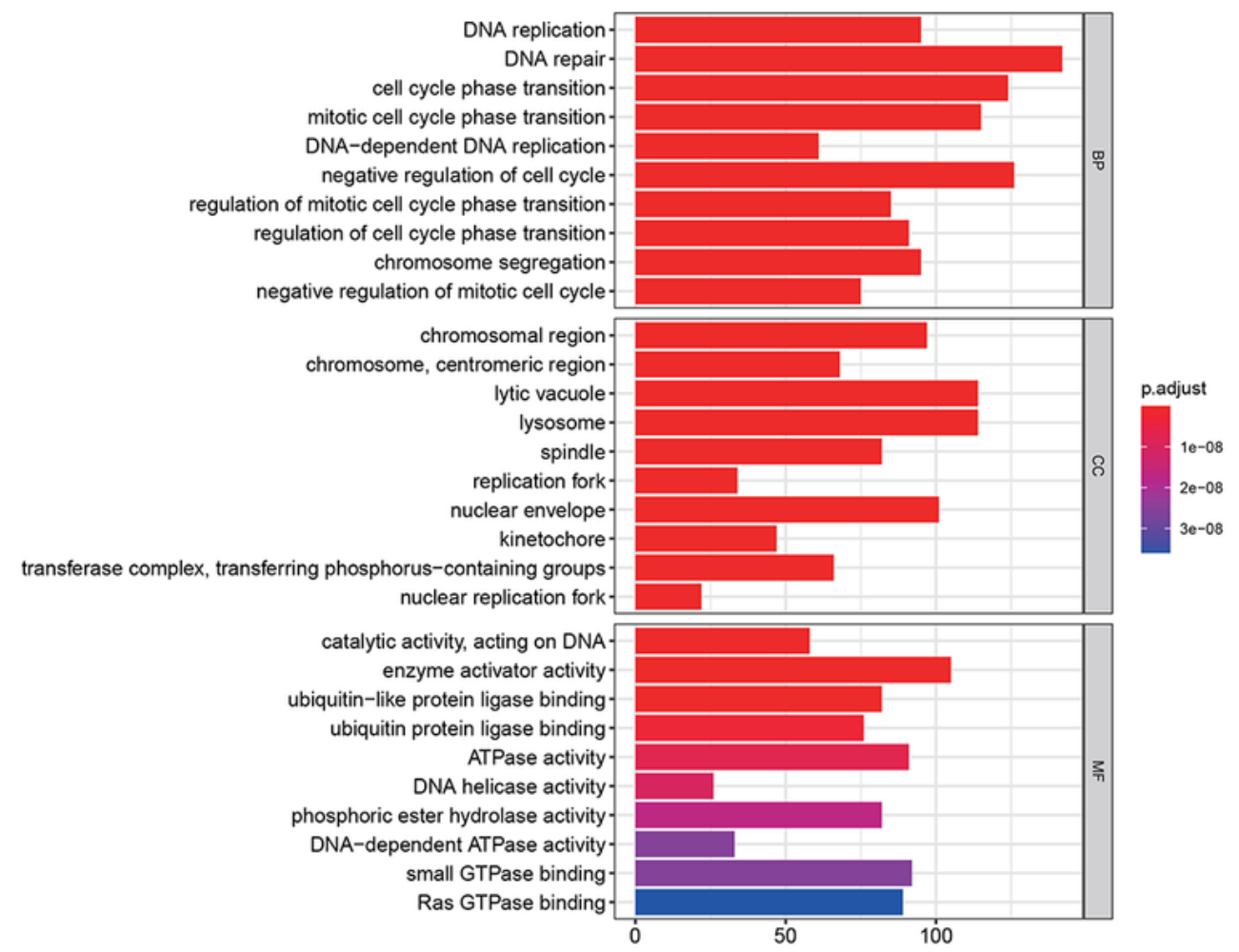

b

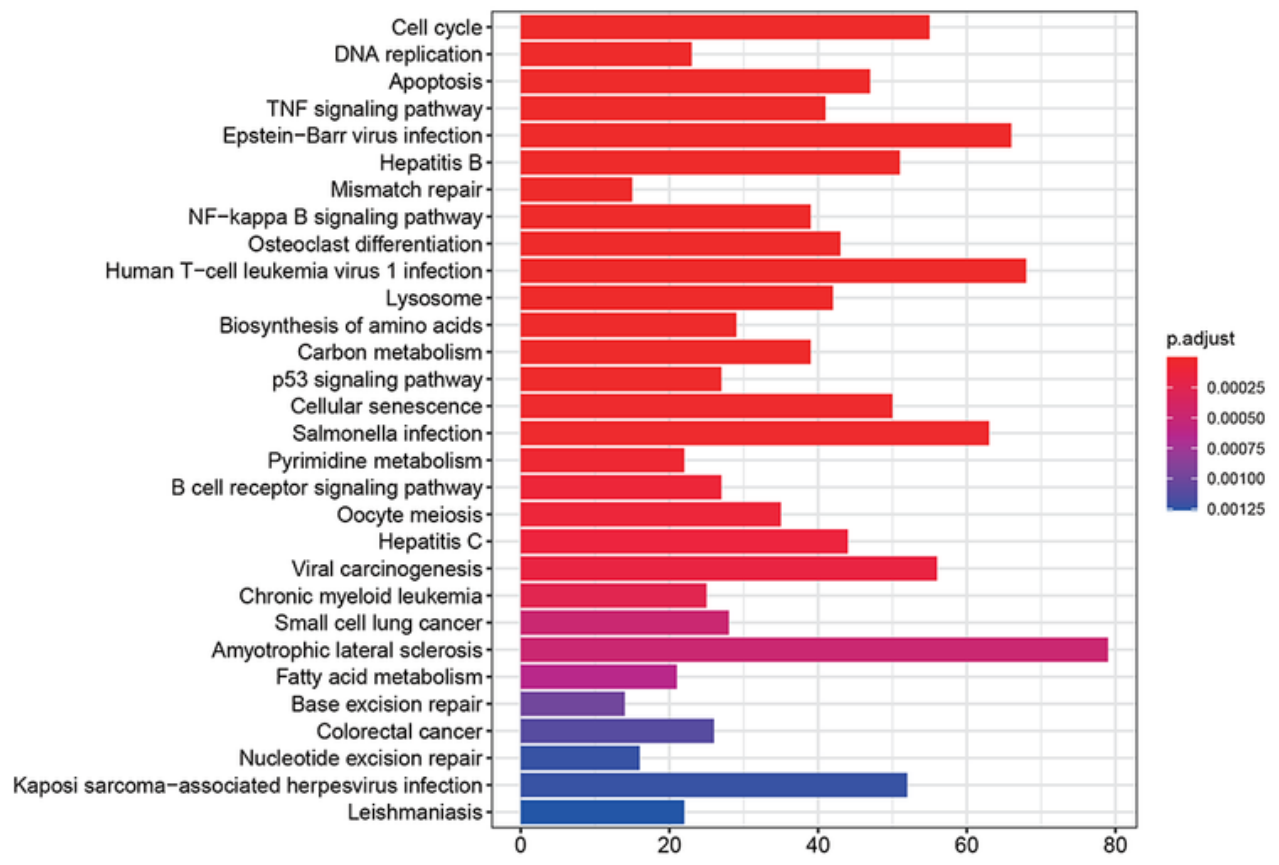

Figure 3

$\mathrm{GO}(\mathrm{A})$ and $\mathrm{KEGG(B)}$ analysis of DEGs. 


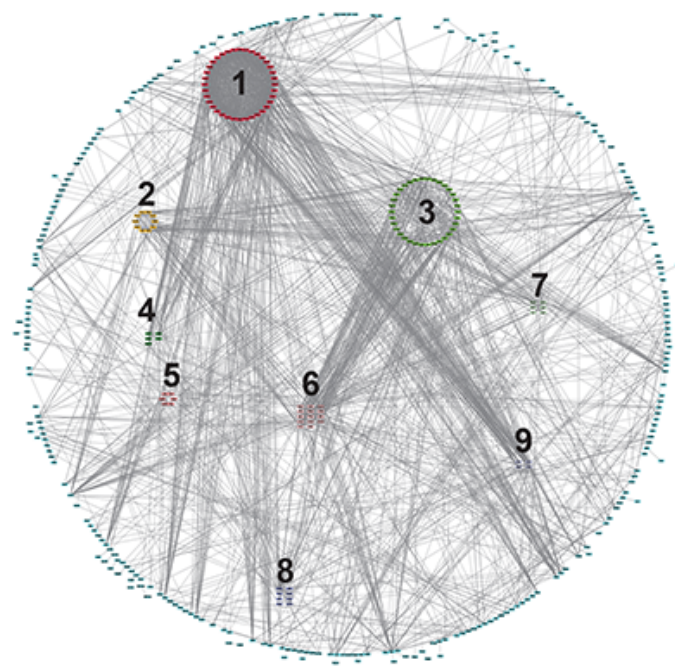

3

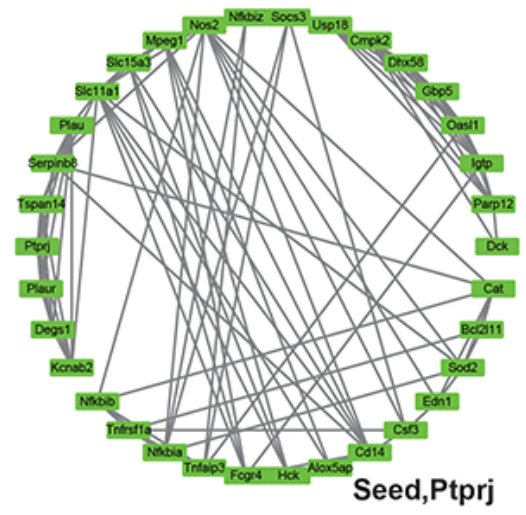

1

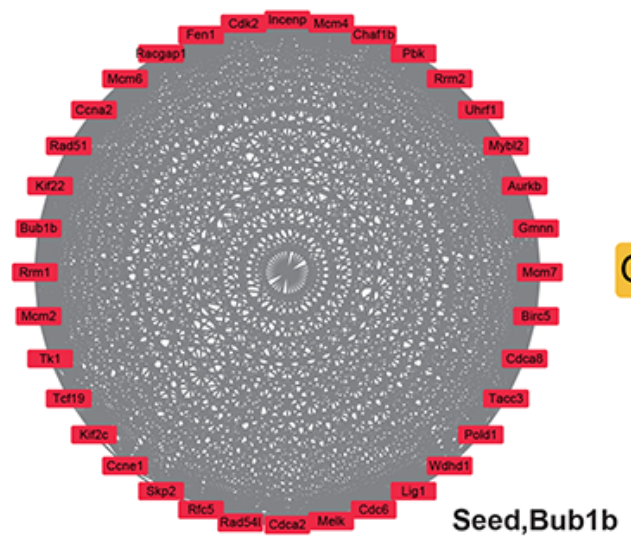

4
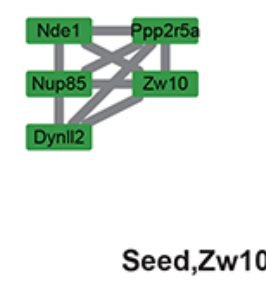

7

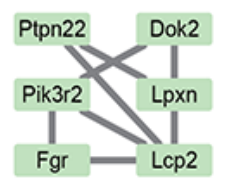

Seed,Dok2
5

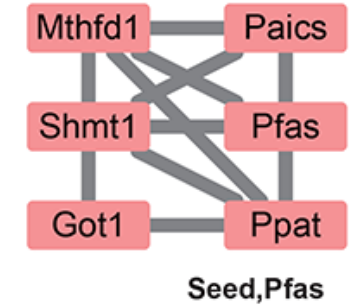

8

Seed,Ezh2

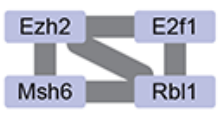

2

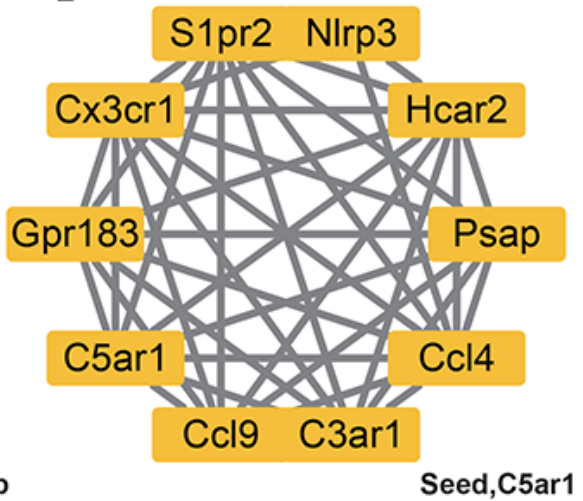

6

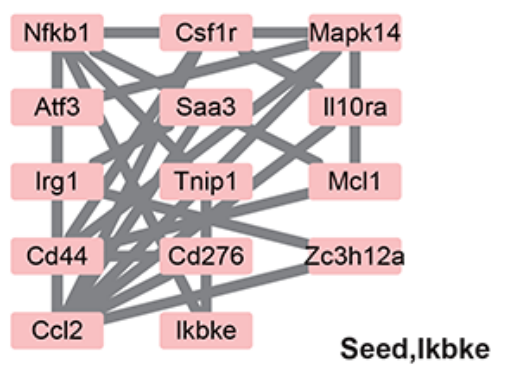

9

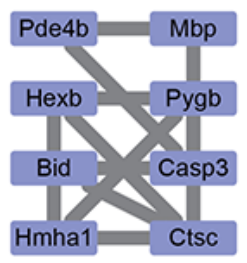

Figure 4

Protein-protein interactions and seed genes of the clusters. 
a

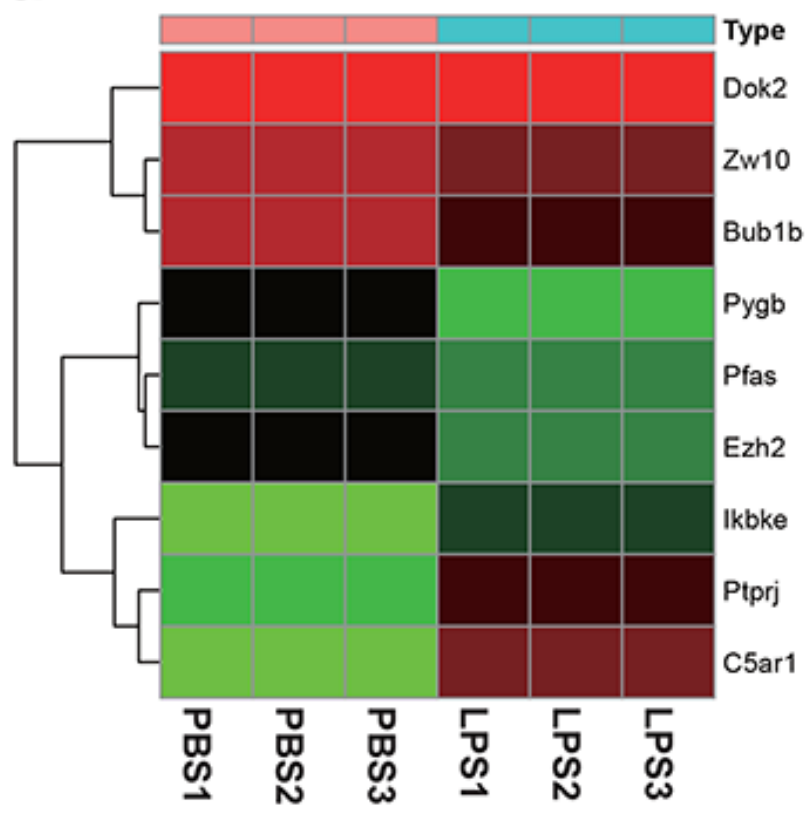

C

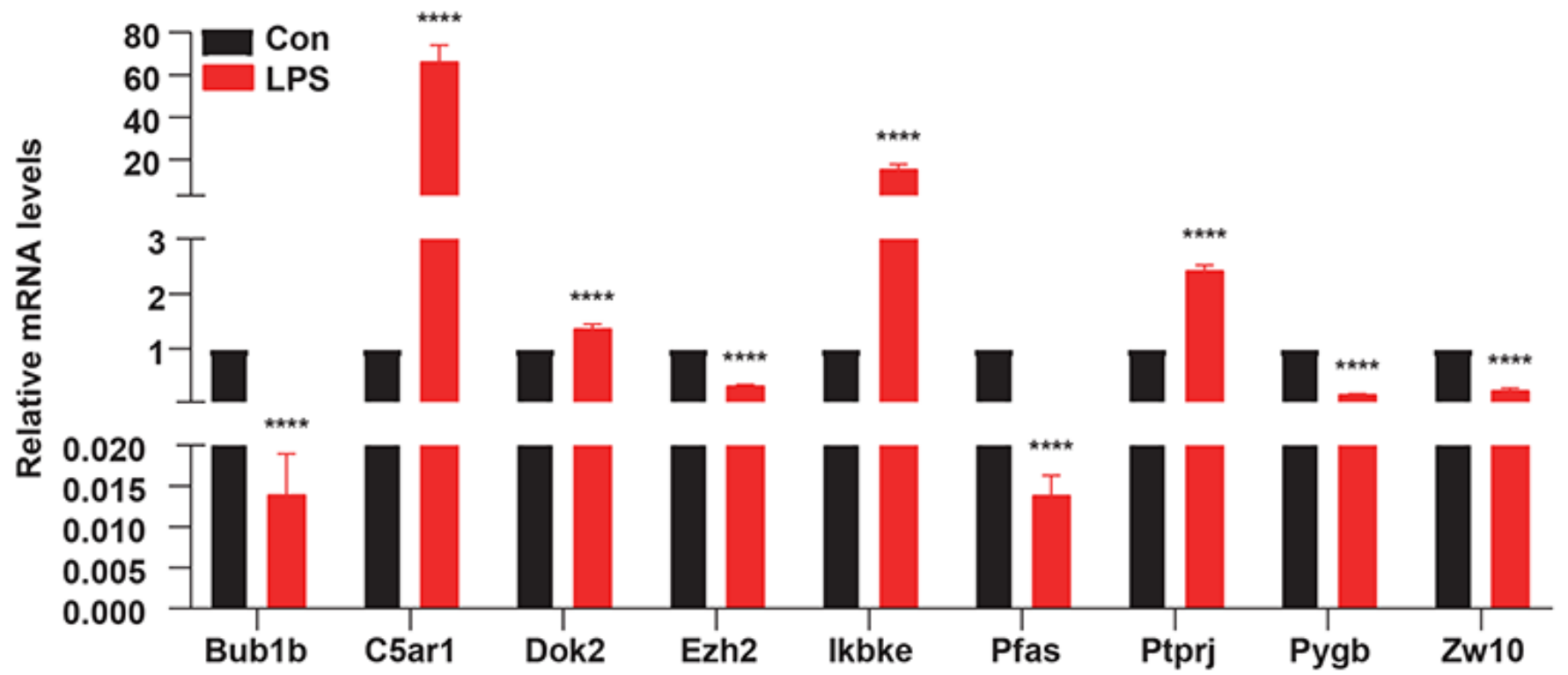

Figure 5

The expression of seed genes. The expression of seed genes in the sequencing data $(A)$ and calculated the $\log F C$ value $(B)$. The qRT-PCR results verified the expression of seed genes (C). ( $n=3-4$ per group, results are the mean $\pm S D$; t-student test. * v.s. Con group. ${ }^{\star \star \star \star *} P<0.0001$ ) 


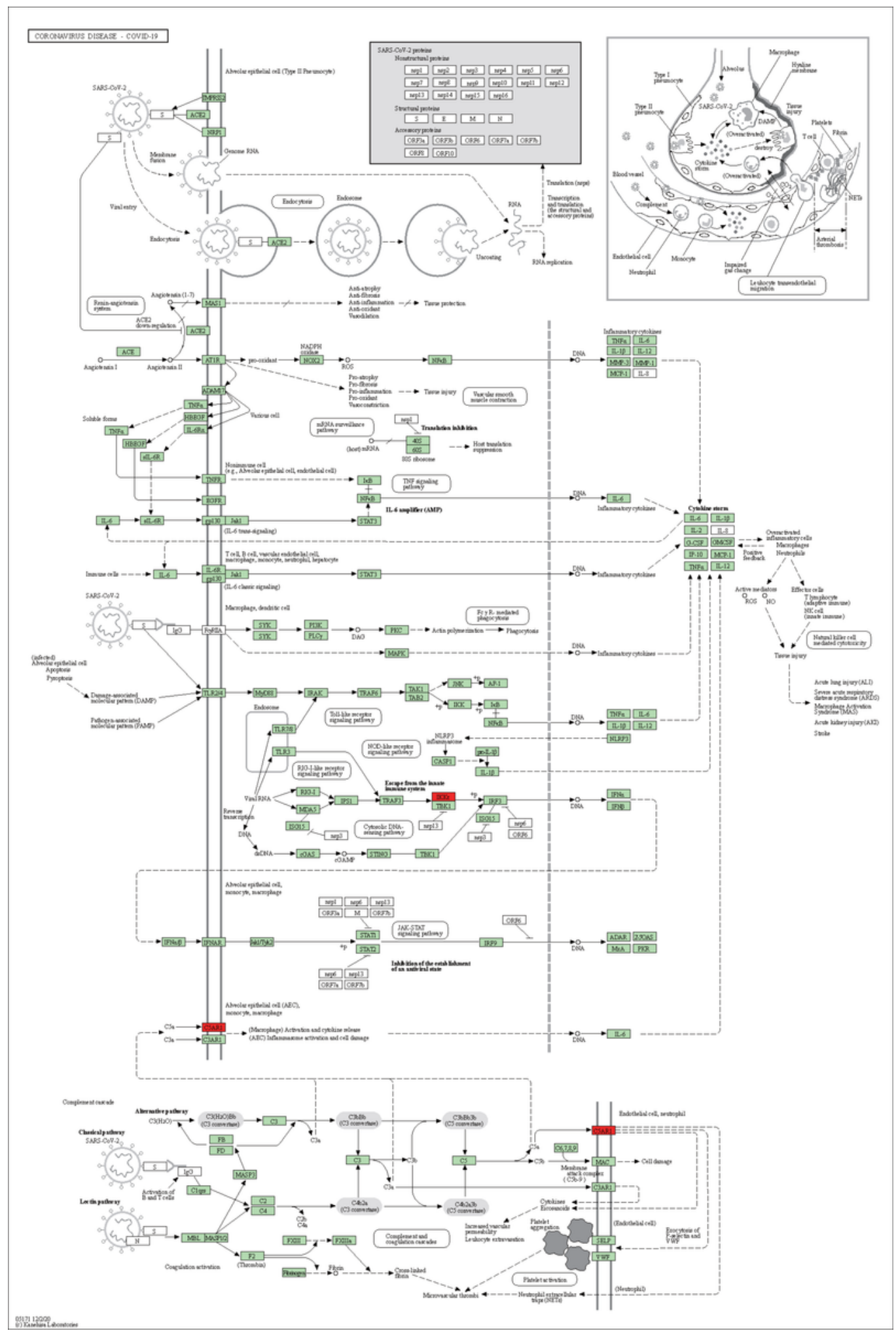

Figure 6

KEGG pathway of coronavirus disease-COVID19. 


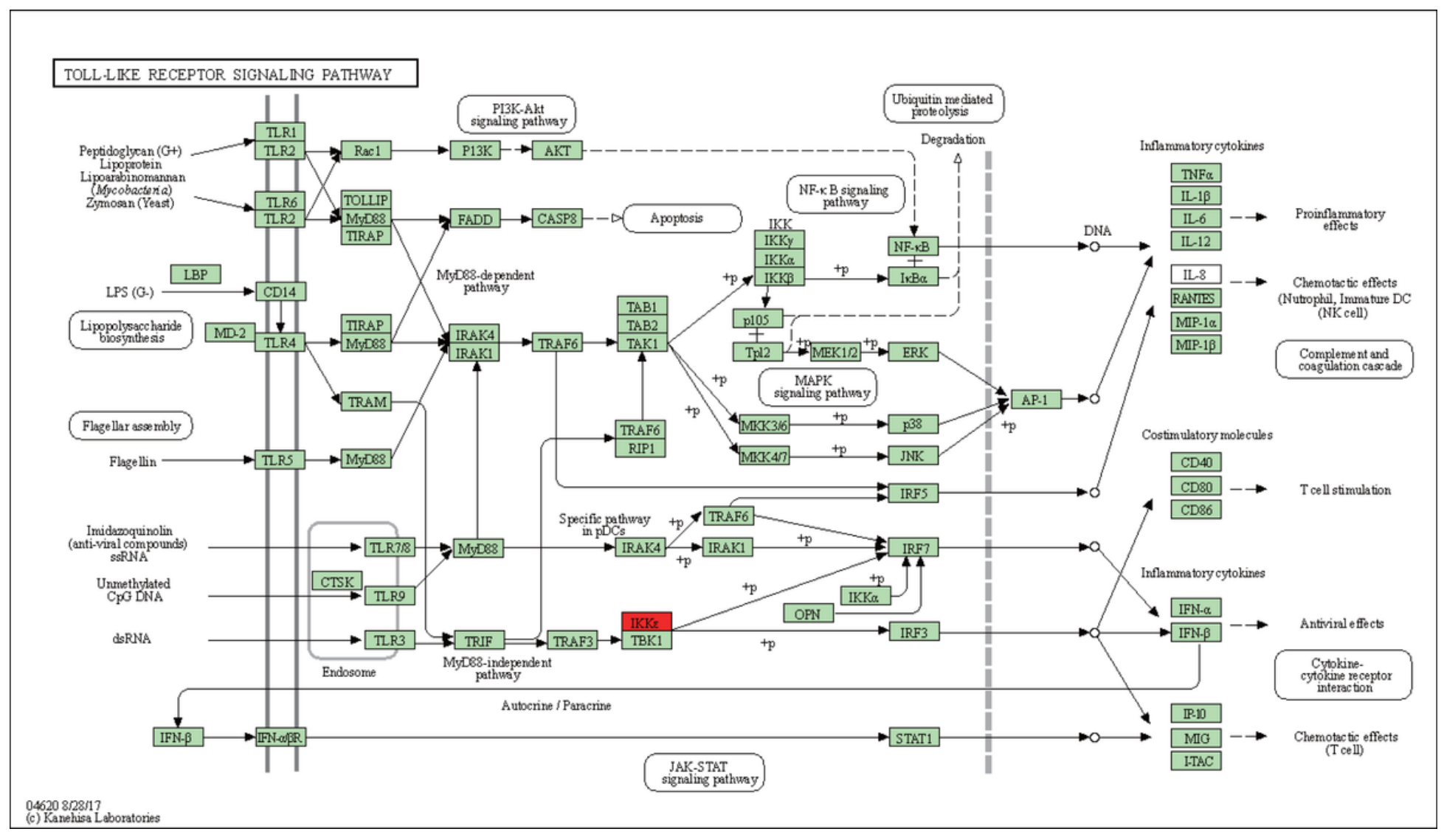

\section{Figure 7}

KEGG pathway of toll-like receptor signaling pathway.

\section{Supplementary Files}

This is a list of supplementary files associated with this preprint. Click to download.

- SupplementalData.pdf 